\title{
Expression of MiR-9 promotes proliferation, migration and differentiation of human neural stem cells
}

\author{
Fei Zeng, Jing Xiong, Wei Ke, Jie Pu, Yanqiang Zhan* \\ Department of Neurology, Renmin Hospital of Wuhan University, Wuhan 430060, China \\ ${ }^{*}$ For correspondence: Email: FrischMbro@yahoo.com; Tel: 0086-27-88041911
}

Sent for review: 30 October 2017

Revised accepted: 24 January 2018

\begin{abstract}
Purpose: To investigate the effect of miR-9 on the proliferation, differentiation and migration of human neural stem cells (NSCs).

Methods: The expression of miR-9 was investigated by quantitative real-time polymerase chain reaction (RT-PCR). Cell proliferation was assessed by cell counting kit-8 (CCK8) assay, while cell migration was studied by Transwell assay. The effect of miR-9 on differentiation of NSCs was investigated by western blot analysis of key differentiation marker proteins. Protein expression was determined by western blotting.

Results: Transfection and over-expression of miR-9 in NSCs significantly enhanced the proliferation of NSCs $(p<0.05)$ in a time-dependent manner, as was evident from CCK8 assay data. MiR-9 overexpression caused down-regulation of Nestin and SOX-2, and up-regulation of Tuj-1 and MAP-2. The migration of NSCs was $37 \%$ in the cells transfected with empty vector, compared to $68 \%$ in the cells transfected with miR-9. This effect of miR-9 on cell migration was accompanied by up-regulation of matrix metallopeptidase 9 (MMP-9) and matrix metallopeptidase 2 (MMP-2).

Conclusion: These results show that miR-9 promotes the proliferation, differentiation and migration of NSCs, and thus may be an important drug target for the generation of NSCs.
\end{abstract}

Keywords: Neural stem cells, MicroRNA, Mir-9, Migration, Differentiation, Proliferation

\begin{abstract}
This is an Open Access article that uses a funding model which does not charge readers or their institutions for access and distributed under the terms of the Creative Commons Attribution License (http://creativecommons.org/licenses/by/4.0) and the Budapest Open Access Initiative (http://www.budapestopenaccessinitiative.org/read), which permit unrestricted use, distribution, and reproduction in any medium, provided the original work is properly credited.

Tropical Journal of Pharmaceutical Research is indexed by Science Citation Index (SciSearch), Scopus, International Pharmaceutical Abstract, Chemical Abstracts, Embase, Index Copernicus, EBSCO, African Index Medicus, JournalSeek, Journal Citation Reports/Science Edition, Directory of Open Access Journals (DOAJ), African Journal Online, Bioline International, Open-J-Gate and Pharmacy Abstracts
\end{abstract}

\section{INTRODUCTION}

Neural stem cells (NSCs) are basically undifferentiated cells with the capacity to divide and self-renew. They also develop into neuronal and glial cells [1-3]. Although (NSCs have received considerable attention and have been thoroughly studied, the molecular mechanisms involved in their proliferation and differentiation have not been thoroughly studied. MicroRNAs are small RNA molecules that do not code for proteins $[4,5]$. They have been reported to play diverse roles. It is believed that the expressions of thousands of genes in humans are regulated by microRNAs. The main processes regulated by microRNAs involve the proliferation and progression of several types of cells [6].

Recently, it was reported that miRNAs are involved in the differentiation of mouse embryonic stem cells (ES). Studies have shown that R-124 (one of the miRNAs) is highly 
expressed during differentiation of $E S$, and that it promotes the differentiation of embryonic tumour P19 cells of mice in vitro $[7,8]$. Similar to miR124, miR-9 has also been reported to be upregulated during the differentiation of several mouse neural stem cells [9].

In the present study, the expression of human NSCs was studied, as well as the effect of miR-9 over-expression on the proliferation, differentiation and migration of human NSCs. This was with a view to elucidating the potential of miR-9 in improving the proliferation and differentiation of NSCs.

\section{EXPERIMENTAL}

Human neural stem cells [Gibco® Human Neural Stem Cells (H9-Derived)] were obtained from Thermos Fisher. The cells were kept in DMEM F12 medium containing L-glutamine $(1 \mathrm{mM}), \mathrm{N}_{2}$ supplement (Gibco-BRL), $20 \mathrm{ng} / \mathrm{mL}$ each of EGF and FGF-2, and $50 \mathrm{ng} / \mathrm{mL}$ heparin. To induce cell differentiation, the cells were cultured in DMEM F12 medium with $\mathrm{N}_{2}$ supplement containing $1 \mu \mathrm{M}$ retinoic acid equivalent to $0.5 \%$ retinoic acid.

\section{Transfection}

The upstream and downstream flanking sequences of miR-9 were amplified with genomic PCR. This was followed by cloning in pMSCv-pur vector. Thereafter, the vector containing miR-9 and the empty vector (negative control) were transfected into NSCs cells with help of FUGENE HD (Promega) as per the manufacturer's protocol. The transfection efficacy was checked by 5'-FAM labelled miR-9 using fluorescence microscopy.

\section{Assessment of expression by quantitative RT-PCR}

For isolation of RNA, RNeasy RNA isolation kit was used as per the instructions of the manufacturer. Thereafter, cDNA was synthesized with the help of RevertAid cDNA synthesis kit (Fermentas) following the manufacturer's protocol. In the RT-PCR assay, the cDNA was diluted 20 times and qRT-PCR was carried out in 3 replicates in $\mathrm{ABI}$ StepOne Real time using SYBR Green Master Mix (Fermentas). Relative quantification method $\left({ }^{\Delta \Delta^{-}} \mathrm{CT}\right)$ was employed to determine quantitative variation in the samples. GAPDH was used as positive control.

\section{Cell proliferation assay}

The viability of the human NSCs, CCK-8 assay was used. The cells were collected at $24,48,72$ and $96 \mathrm{~h}$ after transfection with miR-9 mimics or empty vector, and subjected to CCK-8 assay. Cell viability was assayed by cell numbering kit18 (Dojondo, Japan) in accordance with the manufacturer's guidelines.

\section{Cell migration assay}

Transwell assay was used to investigate the effect of miR-9 on NSC migration. The cells were seeded in twenty-four well plates using polycarbonate membranes with $8-\mathrm{m}$ pores. The NSCs in DMEM F12 medium (100 $\mu \mathrm{L})$ were placed at a density of $1 \times 10^{6} \mathrm{cell} / \mathrm{s} / \mathrm{mL}$ in the upper chamber of the transwell assembly, while $600 \mu \mathrm{L}$ of DMEM F12 medium supplemented with FBS (1\%) and SCF $(100 \mathrm{ng} / \mathrm{mL})$ was placed in the lower chamber. The cells were then incubated for $10 \mathrm{~h}$ at $37^{\circ} \mathrm{C}$. Non-migrating cells were removed by scrapping the upper surfaces of the membranes and washed in PBS. The membranes were thereafter fixed and stained with haematoxylin and eosin ( $H$ \& E).

\section{Western blotting analysis}

Total protein from the neural stem cells was isolated in RIPA lysis buffer. The proteins were quantified by BSA protein assay kit, and equal amounts of protein extract from each group (miR9 and empty vector transfected NSCs) were run on SDS-PAGE and then transferred to a polyvinylidene fluoride membrane. This was followed by blocking with $5 \%$ non-fat milk and incubation at room temperature for $1 \mathrm{~h}$. Thereafter, the membranes were incubated with appropriate primary antibodies overnight at $4{ }^{\circ} \mathrm{C}$. This was followed by washing in washing buffer and incubation for $1 \mathrm{~h}$ with the secondary antibody. The protein bands of interest were visualized by an ECL Advanced Western Blot Detection Kit.

\section{Statistical analysis}

The experiments were carried out in triplicate and the results are presented as mean \pm SD. Student's t-test was used for statistical analysis using GraphPad Prism software, version 7 (GraphPad Software Inc, La Jolla CA, USA). Statistical significance was assumed at $p<0.01$.

\section{RESULTS}

\section{Transfection of NSCs and expression of miR- 9}

It was observed that the expression of miR-9 was about 6.3 times higher in the miR-9 transfected cells, when compared to NSCs transfected with 
empty vector (Figure 1). The transfection efficacy was further checked by fluorescence microscopy and the results showed $76 \%$ transfection (Figure 2). Given these successful transfection results, further experiments were designed accordingly.

\section{Effect of miR-9 on proliferation of NSCs}

The effect of miR-9 transfection on proliferation of NSCs was evaluated through CCK8 assay. The results showed that transfection of NSCs with miR-9 led to significant and time-dependent enhancement of the proliferation of NSCs (Figure 3).

\section{Effect of miR-9 on the differentiation of NSCs}

The results of western blot analysis showed that miR-9 over-expression in NSCs caused significant down-regulation of Nestin and SOX-2, and significant increases in the expressions of Tuj-1 and MAP-2 (Figure 4). These results show that miR-9 promoted the differentiation of NSCs.

\section{Effect of miR-9 on the migration of NSCs}

Results from transwell assay showed that overexpression of miR-9 in NSCs enhanced their capacity to migrate. There was $32 \%$ cell migration in the NSCs transfected with empty vector, relative to $68 \%$ cell migration in the NSCs transfected with miR-9-containing vector (Figure 5). To further validate these results, it was observed that the expressions of MMP-2 and MMP-9 were upregulated in the NSCs transfected with miR-9 (Figure 6). Taken together, these results clearly indicate that miR-9 enhanced the migration of NSCs.

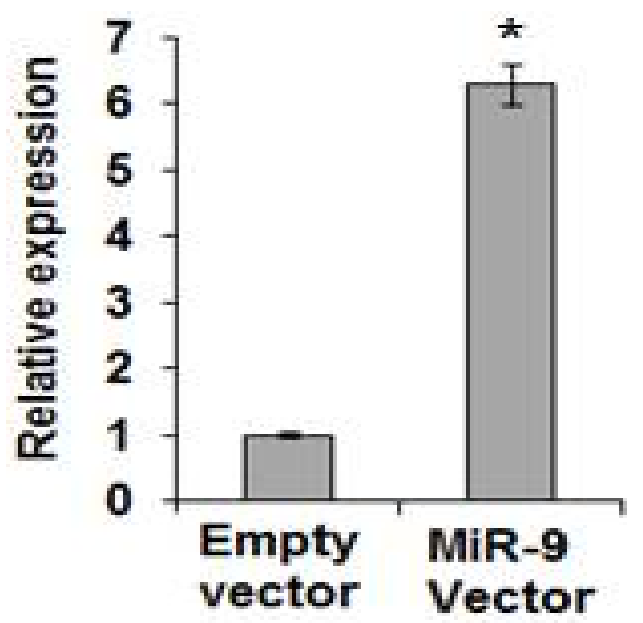

Figure 1: Relative expression of miR-9 in miR-9 transfected NSCs, and empty vector-transfected NSCs. Results are expressed as mean \pm SD of three replicates; ${ }^{*} p<0.05$ relative to empty vectortransfected NSCs
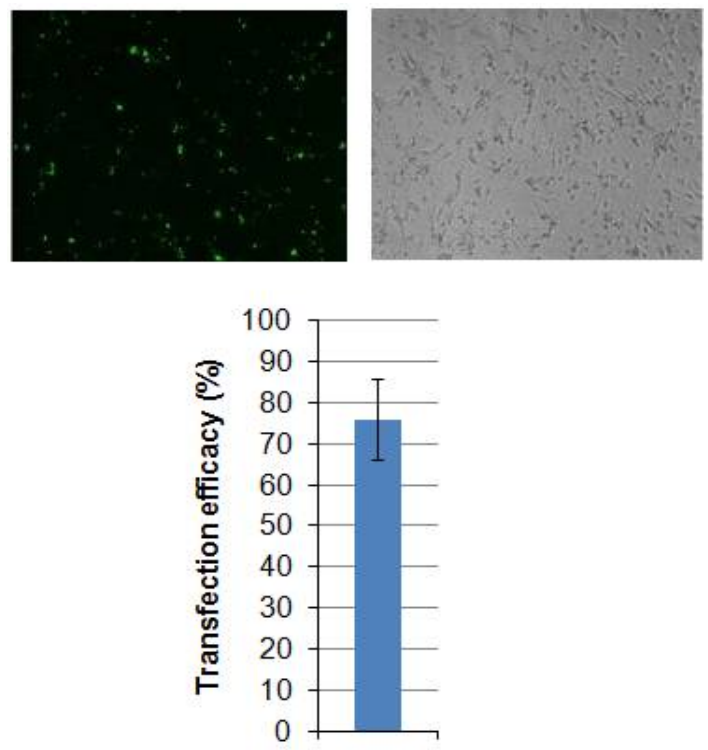

Figure 2: Transfection efficacy via fluorescence microscopy. Each experiment was carried out in triplicates, and results are expressed as mean \pm SD

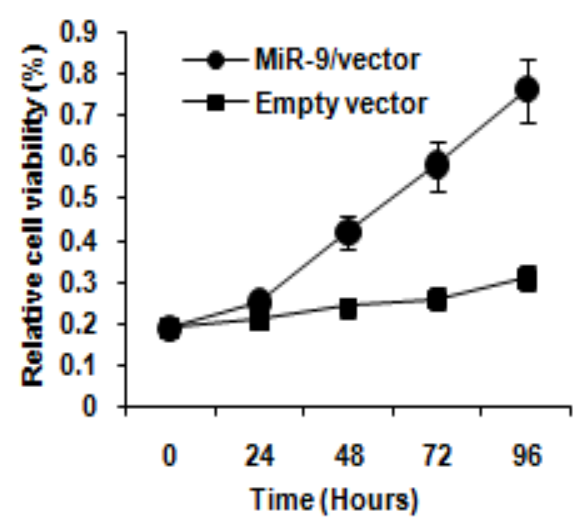

Figure 3: Relative cell viability of NSCs transfected with miR-9 or empty vector. The experiments were carried out in triplicates, and results are expressed as mean \pm SD

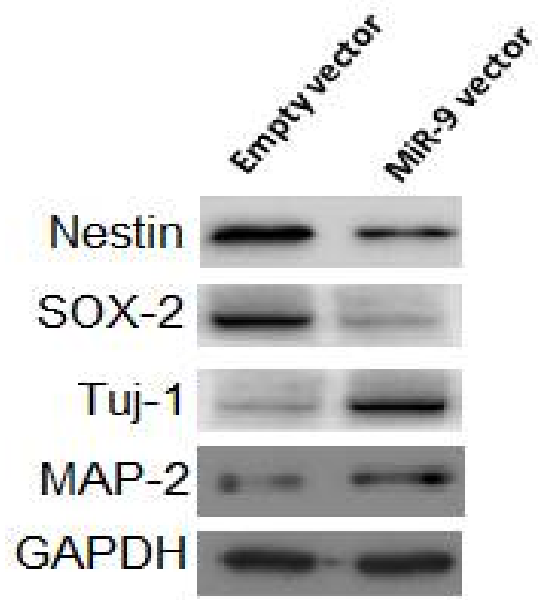

Figure 4: Western blot showing the expressions of Nestin, SOX-2, Tuj-1 and MAP-2 in empty vector- and miR-9-transfected NSCs 


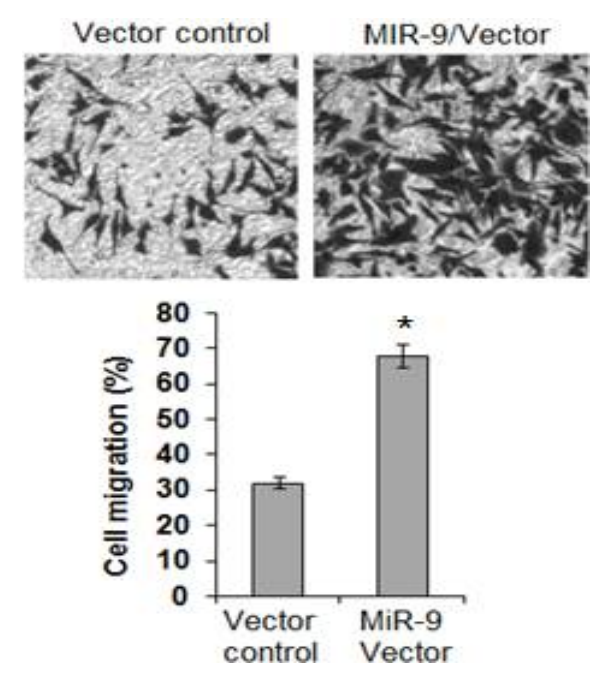

Figure 5: Cell migration capacity of NSCs transfected with empty vector or miR-9 as determined by transwell migration assay. Each experiment was carried out in triplicate, and the results are expressed as mean \pm $\mathrm{SD} ;{ }^{*} p<0.05$

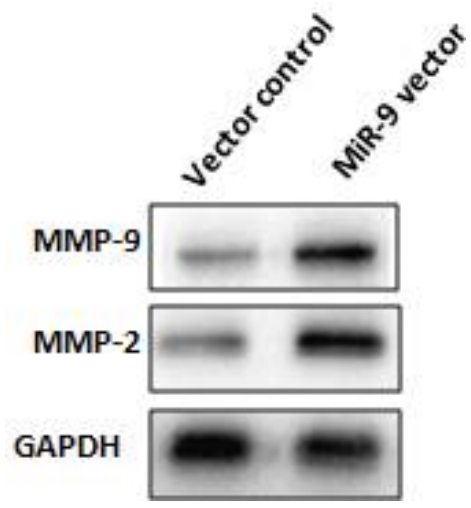

Figure 6: Western blots showing the expressions of MMP-9 and MMP-2 in empty vector- and miR-9transfected NSCs

\section{DISCUSSION}

Human NSCs are self-renewing, multipotent cells capable of giving rise to the main phenotypes of the nervous system [10]. Several studies have been carried out on the potential clinical applications of NSCs [11]. It has been reported that NSCs could be beneficial in the treatment of neurological disorders such brain trauma and spinal cord injury [2]. Whereas the functional properties of NSCs have been studied to some extent [13], the mechanisms that govern their renewal, differentiation and migration have not been fully explored.

MicroRNAs have been reported to play vital roles in a diversity of cellular processes by regulating the expression of a number of genes. They are considered as therapeutic targets for the treatment of cancer, and they are currently thought to be important for understanding the mechanism behind the renewal and differentiation of NSCs $[14,15]$. MiR-9 has been previously reported to be significantly expressed in NSCs. In the current study, the effect of miR-9 over-expression on proliferation, differentiation and migration of NSCs was investigated. The results showed that miR-9 over-expression in NSCs enhanced their proliferation in a timedependent manner. These results are in agreement with a previous study in which miR-9 was found to regulate the proliferation of cancer cells [16]. In addition, it was observed that miR-9 over-expression in NSCs promoted their differentiation by inducing changes in the expression of several marker proteins for cell differentiation: the protein expressions of Nestin and SOX-2 were decreased, while the expressions of Tuj-1 and MAP-2 were significantly increased.

These observations suggest that miR-9 probably regulated the differentiation of NSCs by controlling the expressions of these proteins. These findings are in agreement with previous reports in which microRNAs were shown to regulate the expressions of Nestin, SOX-2, Tuj-1 and MAP-2 [17]. Results from transwell migration assay revealed that miR-9 increased the migration potential of NSCs. The increase in migration was also associated with enhanced expressions of MMP-9 and MMP-2. Taken together, these results provide new and useful insights for understanding the mechanisms that control NSC proliferation and differentiation.

\section{CONCLUSION}

The findings of this study demonstrate that miR-9 regulates the proliferation, differentiation and migration of NSCs. These results are considered helpful for unravelling some of the molecular mechanisms that regulate the proliferation and differentiation of NSCs. Thus, further studies on miR-9 will enhance knowledge on the molecular mechanisms involved in the renewal of NSCs.

\section{DECLARATIONS}

\section{Acknowledgement}

We acknowledge the Department of Neurology, Renmin Hospital of Wuhan University for the use of its facilities.

\section{Conflict of interest}

No conflict of interest is associated with this work. 


\section{Contribution of authors}

We declare that this work was done by the authors named in this article and all liabilities pertaining to claims relating to the content of this article will be borne by the authors. The experiments in this study were done by Fei Zeng with the help of Jing Xiong. Wei Ke, Jie Pu reviewed this manuscript and gave comments for designing this study. Yanqiang Zhan drafted this manuscript and supervised the other authors.

\section{REFERENCES}

1. Galli R, Gritti A, Bonfanti L, Vescovi AL. Neural stem cells. Circulation res 2003; 92(6): 598-608.

2. Doetsch F, Caille I, Lim DA, García-Verdugo JM, AlvarezBuylla A. Subventricular zone astrocytes are neural stem cells in the adult mammalian brain. Cell 1999; 97(6): 703-716.

3. Bjornson CR, Rietze RL, Reynolds BA, Magli MC, Vescovi AL. Turning brain into blood: a hematopoietic fate adopted by adult neural stem cells in vivo. Sci 1999; 283(5401): 534-537.

4. Bartel DP. MicroRNAs: genomics, biogenesis, mechanism, and function. Cell 2004; 116(2): 281-297.

5. Bartel DP. MicroRNAs: target recognition and regulatory functions. Cell 2009; 136(2): 215-233.

6. Garzon R, Calin GA, Croce CM. MicroRNAs in cancer. Annual rev Med 2009; 60: 167-179.

7. Yu JY, Chung KH, Deo M, Thompson RC, Turner DL. MicroRNA miR-124 regulates neurite outgrowth during neuronal differentiation. Experimental Cell Res 2008; 314(14): 2618-2633.

8. Visvanathan J, Lee $S$, Lee B, Lee JW, Lee SK. The microRNA miR-124 antagonizes the anti-neural
REST/SCP1 pathway during embryonic CNS development. Genes Dev 2007; 21(7): 744-749.

9. Zhao C, Sun G, Li S, Shi Y. A feedback regulatory loop involving microRNA-9 and nuclear receptor TLX in neural stem cell fate determination. Nature Struct Molecular Biol 2009; 16(4): 365-371.

10. Alvarez-Buylla A, García-Verdugo JM, Tramontin AD. A unified hypothesis on the lineage of neural stem cells. Nat Rev Neurosci 2001; 2(4): 287-293.

11. Ehtesham M, Kabos $P$, Kabosova A, Neuman $T$, Black $K L$, John SY. The use of interleukin 12-secreting neural stem cells for the treatment of intracranial glioma. Canc Res 2002; 62(20): 5657-5663.

12. Kiskinis E, Eggan K. Progress toward the clinical application of patient-specific pluripotent stem cells. J Clin Invest 2010; 120(1): 51.

13. Daadi MM, Maag AL, Steinberg GK. Adherent selfrenewable human embryonic stem cell-derived neural stem cell line: functional engraftment in experimental stroke model. PLoS One 2008; 3(2): e1644.

14. Krichevsky AM, Sonntag KC, Isacson O, Kosik KS. Specific microRNAs modulate embryonic stem cellderived neurogenesis. Stem cells 2006; 24(4): 857-864.

15. Silber J, Lim DA, Petritsch C, Persson Al, Maunakea AK, $Y u$, Vandenberg $S R$, Ginzinger DG, James $C D$, Costello JF, Bergers G. miR-124 and miR-137 inhibit proliferation of glioblastoma multiforme cells and induce differentiation of brain tumor stem cells. BMC Med 2008; 6(1): 14.

16. Selcuklu SD, Donoghue MT, Rehmet $K$, de Souza Gomes M, Fort A, Kovvuru P, Muniyappa MK, Kerin MJ, Enright AJ, Spillane C. MicroRNA-9 inhibition of cell proliferation and identification of novel miR-9 targets by transcriptome profiling in breast cancer cells. $\mathrm{J}$ Biol Chem 2012; 287(35): 29516-29528.

17. Nguyen LH, Diao HJ, Chew SY. MicroRNAs and their potential therapeutic applications in neural tissue engineering. Adv Drug Del Rev 2015; 88: 53-66. 